\title{
DKK3 is a potential tumor suppressor gene in papillary thyroid carcinoma
}

\author{
De-tao Yin ${ }^{1,2}$, Wenxun $\mathrm{Wu}^{3}$, Mingchuang $\mathrm{Li}^{1,2}$, Qi-en Wang ${ }^{4}$, Hongqiang $\mathrm{Li}^{1,2}$, \\ Yongfei Wang ${ }^{1,2}$, Yifeng Tang ${ }^{1,2}$ and Mingzhao Xing ${ }^{5}$ \\ ${ }^{1}$ Department of Thyroid Surgery, The First Affiliated Hospital, Zhengzhou University, Zhengzhou 450052, \\ People's Republic of China \\ ${ }^{2}$ Key Discipline Laboratory of Clinical Medicine Henan, Zhengzhou 450052, People's Republic of China \\ ${ }^{3}$ Department of Endocrinology, The First Affiliated Hospital, Zhengzhou University, Zhengzhou 450052, \\ People's Republic of China \\ ${ }^{4}$ Division of Radiobiology, Department of Radiology, The Ohio State University, Columbus, Ohio 43210, USA \\ ${ }^{5}$ Division of Endocrinology and Metabolism, The Johns Hopkins University School of Medicine, Baltimore, \\ Maryland 21287, USA
}

\author{
Correspondence \\ should be addressed to \\ D Yin or M Xing \\ Email \\ detaoyin@zzu.edu.cn or \\ mxing1@jhmi.edu
}

\begin{abstract}
The expression of the Dickkopf homolog $3(D K K 3)$ gene is downregulated in some human cancers, suggesting a possible tumor suppressor role of this gene. The role and regulation of $D K K 3$ in thyroid cancer have not been examined. In this study, we explored the relationship of promoter methylation with the inactivation of $D K K 3$ and tumor behaviors in papillary thyroid carcinoma (PTC). We used methylation-specific PCR and RT-PCR to examine the promoter methylation and expression of $D K K 3$ and tumor characteristics. We found mRNA expression of $D K K 3$ in $44.9 \%$ of the PTC tissue samples vs $100 \%$ of the matched normal thyroid tissue samples $(P<0.01)$. In contrast, an opposite distribution pattern of $D K K 3$ gene methylation was observed; specifically, $38.8 \%$ of the PTC tissue samples vs $0 \%$ of the matched normal thyroid tissue samples harbored $D K K 3$ methylation. An inverse correlation between the promoter methylation and mRNA expression of $D K K 3$ in PTC tissue samples was also observed. Moreover, we also found an inverse correlation between $D K K 3$ expression and some aggressive pathological characteristics of PTC, including high TNM stages and lymph node metastasis, but a positive correlation between $D K K 3$ promoter hypermethylation and pathological aggressiveness of the tumor. Treatment of the PTC cell line TPC-1 with the demethylating agent $5-a z a C$ reduced $D K K 3$ promoter methylation and enhanced its expression, establishing functionally the impact of $D K K 3$ methylation on its expression. Our data thus for the first time demonstrate that the $D K K 3$ gene is a potential tumor suppressor gene in thyroid cancer and that aberrant promoter methylation is an important mechanism for its downregulation, which may play a role in the tumorigenesis and aggressiveness of PTC.
\end{abstract}

\section{Key Words}

- thyroid carcinoma

- DKK3

- DNA methylation

- tumor suppressor gene

thyroid tumorigenesis
Endocrine-Related Cancer (2013) 20, 507-514

\section{Introduction}

Thyroid carcinoma is the most common endocrine malignancy, and papillary thyroid carcinoma (PTC) accounts for over $90 \%$ of all thyroid malignancies
(Yin et al. 2010a). The incidence of thyroid cancer, mainly PTC, has been rising rapidly in recent decades worldwide (Davies \& Welch 2006). It has been well established that 
both genetic and epigenetic alterations contribute to carcinogenesis (Yin et al. 2011). In particular, hypermethylation of $\mathrm{CpG}$ islands in the promoter regions of tumor suppressor genes (TSGs) is commonly observed in various cancers, including thyroid cancer (Xing 2007). DNA methylation is a common epigenetic event observed in mammalian genomes, and it often mediates transcriptional repression (Aleqria-Torres et al. 2011). It has been reported that many TSGs are hypermethylated in PTC (Lal et al. 2006, Xing 2007, Yin et al. 2010b, Stephen et al. 2011).

The Dickkopf (DKK) family consists of four members that share two conserved cysteine-rich domains (Fong et al. 2009). It has been demonstrated that DKKs, including DKK3, display regionalized expression and control cell fate during development in vertebrates (Monaghan et al. 1999, Suwa et al. 2003, Ang et al. 2004, Diep et al. 2004, Fjeld et al. 2005, Nie 2005). DKK1, DKK2, and DKK4, antagonists of Wnt signaling (Krupnik et al. 1999, Veeck \& Dahl 2012), interact with Wnt coreceptors, LDL receptor-related protein 5/6 (LRP5/6) and kremen proteins (Davidson et al. 2002, Mao et al. 2002). DKK3 interacts with kremen1 and 2, but not with LRP5/6 (Nakamura \& Hackam 2010). Among the DKK family members, REIC/DKK3 is rather unique with regard to the homology analysis of the DNA sequence, expression profiles, and biological functions (Glinka et al. 1998, Krupnik et al. 1999). The DKK3 protein is ubiquitously expressed in mouse and normal human tissues, but its expression is significantly downregulated in several cancers (Abarzua et al. 2005, Zhang et al. 2010). However, the expression and role of DKK3 in thyroid cancer have not been examined. To better understand the role of $D K K 3$ in PTC, we investigated and compared DKK3 expression and promoter methylation in PTC tissues and their adjacent normal tissues. Our data demonstrated that DKK3 expression is markedly reduced in primary PTC tissues than in normal thyroid tissues. We also provided evidence that the loss of $D K K 3$ expression in PTC is predominantly mediated by the hypermethylation of the $D K K 3$ promoter, thus identifying $D K K 3$ as a potentially important TSG in PTC.

\section{Materials and methods}

\section{Materials}

Thyroid tumor and adjacent normal thyroid tissue samples were obtained from 49 thyroid carcinoma patients during the primary thyroid surgery at The First Affiliated Hospital of Zhengzhou University under an Institutional Review Board-approved protocol at Zhengzhou University, between October 2010 and April 2011. After collection, tissue samples were immediately snap-frozen in liquid nitrogen and stored at $-80^{\circ} \mathrm{C}$.

The patients comprised 18 males and 31 females with ages ranging between 15 and 75 years (median age, 45 years). The patients had not undergone prior chemotherapy or radiotherapy. The clinicopathological staging of PTC was made based on the TNM classification system introduced in 2002 by the American Joint Committee on Cancer (Greene et al. 2002; New York, Springer-Verlag). Among the patients, 19 had grade I and 30 had grade II carcinomas according to histological grading. By clinical staging using TNM standards, 4 patients had stage I, 18 had stage II, 26 had stage III, and 1 had stage IV carcinomas. The presence of lymphatic metastasis in regional nodes was confirmed pathologically and was positive in 28 patients.

\section{Cell culture}

TPC-1 cell line was kindly provided by Dr Ye Lei (Shanghai Rui Jin Hospital). TPC-1 cells were cultured and maintained in RPMI-1640 medium with $10 \%$ fetal bovine serum according to ATCC propagation guidelines in a humidified incubator with $5 \% \mathrm{CO}_{2}$ at $37^{\circ} \mathrm{C}$.

\section{RT-PCR}

Total RNA was isolated with the TRIzol reagent (Invitrogen) as described by the manufacturer. One microgram of total RNA was reverse transcribed into cDNA using the Reverse Transcriptase and oligo (dT; Fermentas, Burlington, Ontario, Canada). To detect DKK3 by PCR, the sense primer, 5'-ACAGCCACAGCCTGGTGTA- $3^{\prime}$ and antisense primer, 5'-CCTCCATGAAGCTGCCAAC-3' were used (Veeck et al. 2008), resulting in a PCR product of $120 \mathrm{bp}$. GAPDH was also detected as a control, using the following primers: sense primer, 5'-GACCACAGTCCATGCCATCAC- $3^{\prime}$ and antisense primer, 5'-GTCCACCACCCTGTTGCTGTA- $3^{\prime}$. The length of amplified GAPDH was $454 \mathrm{bp}$. PCR consisted of an initial denaturation step at $95^{\circ} \mathrm{C}$ for $30 \mathrm{~s}$, followed by 29 cycles of $94^{\circ} \mathrm{C}$ for $30 \mathrm{~s}, 66^{\circ} \mathrm{C}$ for $30 \mathrm{~s}, 72^{\circ} \mathrm{C}$ for $30 \mathrm{~s}$, and a final extension step at $72{ }^{\circ} \mathrm{C}$ for $5 \mathrm{~min}$ and $4{ }^{\circ} \mathrm{C}$ to stop the reaction. The resulting PCR product was resolved by $2 \%$ agarose gel electrophoresis and stained with ethidium bromide. The intensities of the DKK 3 band were analyzed using the Quantity One Software and normalized to those of the GAPDH band. The results obtained from the tumor

Published by Bioscientifica Ltd. 
A
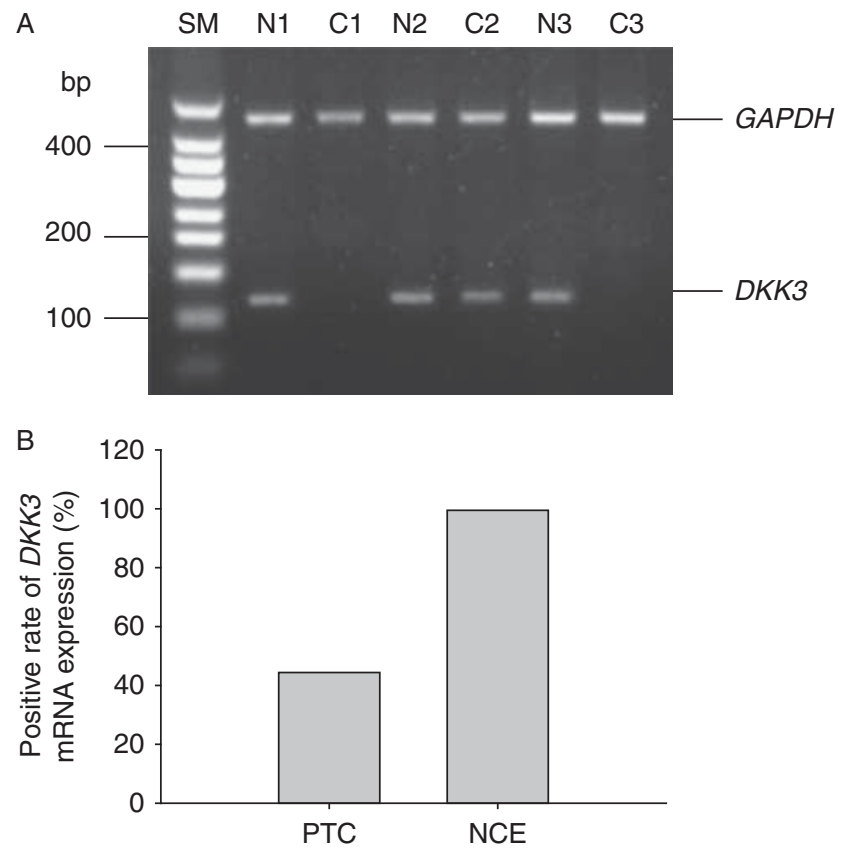

Figure 1

(A) Representative images of DKK3 mRNA expression in PTC tissues and the adjacent non-cancerous epithelial tissues, detected using RT-PCR. (B) Positive rate of DKK3 mRNA expression in 49 PTC tissue samples and their adjacent non-cancerous epithelial tissue samples. SM, Standard Marker DL-500; C, cancer tissue of PTC; N, matched adjacent non-cancerous epithelial tissues; PTC, papillary thyroid cancer; NCE, non-cancerous epithelial tissues. tissue samples were compared with those obtained from the matched normal tissue samples (average). A result greater than this value or in this value range was considered positive gene expression. A result below this value or absent was considered low or absent expression (for statistical analyses, both were considered impaired/ negative gene expression).

\section{Methylation-specific PCR}

To analyze the methylation status of the promoter of the $D K K 3$ gene, we used previously reported primers (Veeck et al. 2008). Extraction of genomic DNA (gDNA) was carried out using a gDNA extraction kit (BioTeke, Beijing, China). The snap-frozen samples were dissolved in the lysis buffer followed by DNA isolation. Bisulfite-modified gDNA was prepared using the EZ DNA Methylation-Gold Kit (Zymo Research, Orange, CA, USA) according to manufacturer's instructions. For the bisulfite reaction, $400 \mathrm{ng}$ gDNA and $130 \mu \mathrm{l} \mathrm{CT}$ conversion reagent were used. Sample tubes were placed in a thermal cycler (MJ Research, Waltham, MA, USA), and the following steps were carried out: $10 \mathrm{~min}$ at $98^{\circ} \mathrm{C}$ and $2.5 \mathrm{~h}$ at $64^{\circ} \mathrm{C}$, and then stored at $4{ }^{\circ} \mathrm{C}$. The resultant DNA was purified using the EZ DNA MethylationGold kit. DNA samples were finally stored at $-20^{\circ} \mathrm{C}$ for further study. PCR was performed using a volume of $50 \mu \mathrm{l}$. Amplification was carried out according to the general

Table 1 Relationship between DKK3 mRNA expression and clinicopathological features in PTC.

\begin{tabular}{|c|c|c|c|c|c|c|}
\hline \multirow[b]{2}{*}{ Clinical data } & \multirow[b]{2}{*}{$\boldsymbol{n}$} & \multicolumn{2}{|c|}{ Expression of mRNA } & \multirow[b]{2}{*}{ Positive rate $(\%)$} & \multirow[b]{2}{*}{$\chi^{2}$} & \multirow[b]{2}{*}{$\boldsymbol{P}$} \\
\hline & & Positive & Negative & & & \\
\hline \multicolumn{7}{|l|}{ Gender } \\
\hline Male & 18 & 6 & 12 & 33.3 & 1.538 & 0.215 \\
\hline Female & 31 & 16 & 15 & 51.6 & & \\
\hline \multicolumn{7}{|l|}{ Age (years) } \\
\hline$<45$ & 23 & 10 & 13 & 43.5 & 0.035 & 0.851 \\
\hline$\geq 45$ & 26 & 12 & 14 & 46.2 & & \\
\hline \multicolumn{7}{|l|}{ Tumor size $(\mathrm{cm})$} \\
\hline$<2$ & 24 & 9 & 15 & 37.5 & 1.041 & 0.308 \\
\hline$\geq 2$ & 25 & 13 & 12 & 52.0 & & \\
\hline \multicolumn{7}{|l|}{ TNM stage } \\
\hline I-II & 22 & 15 & 7 & 68.2 & 8.749 & $0.003 *$ \\
\hline III-IV & 27 & 7 & 20 & 26.0 & & \\
\hline \multicolumn{7}{|l|}{ Tumor pathological grade } \\
\hline I & 19 & 12 & 7 & 63.2 & 4.182 & $0.041^{\dagger}$ \\
\hline II & 30 & 10 & 20 & 33.3 & & \\
\hline \multicolumn{7}{|l|}{ Lymph node metastasis } \\
\hline No & 21 & 13 & 8 & 62.0 & 4.296 & $0.038^{\dagger}$ \\
\hline Yes & 28 & 9 & 19 & 32.1 & & \\
\hline \multicolumn{7}{|l|}{${ }^{\star} P<0.01$ and ${ }^{\dagger} P<0.05$} \\
\hline $\begin{array}{l}\text { http://erc.endocrinology-journals.org } \\
\text { DOI: 10.1530/ERC-13-0053 }\end{array}$ & & $\begin{array}{l}\text { for Endocr } \\
\text { ed in Great }\end{array}$ & & tifica Ltd. & & \\
\hline
\end{tabular}


guidelines suggested for pyrosequencing (TakaRa Taq Hot Start Version; Takara, Dalian, Shandong, China): denaturation at $95^{\circ} \mathrm{C}$ for $5 \mathrm{~min}, 35$ cycles at $94^{\circ} \mathrm{C}$ for $30 \mathrm{~s}$, $60^{\circ} \mathrm{C}$ for $30 \mathrm{~s}$ for unmethylated primers and $58^{\circ} \mathrm{C}$ for $30 \mathrm{~s}$ for methylated primers, $72^{\circ} \mathrm{C}$ for $45 \mathrm{~s}$, and the final extension at $72{ }^{\circ} \mathrm{C}$ for $5 \mathrm{~min}$ and $4{ }^{\circ} \mathrm{C}$ to stop the reaction. The PCR product $(5 \mu \mathrm{l})$ was confirmed by electrophoresis on $2 \%$ agarose gel and visualized by ethidium bromide staining.

\section{Demethylation}

TPC-1 cells were treated with 5-azaC at various concentrations for $48 \mathrm{~h}$. Methylation-specific PCR (MSP) analysis was conducted to evaluate the promoter methylation status of the DKK3 gene in the TPC- 1 cells, and RT-PCR was used to determine the mRNA expression of the DKK3 gene. The sense primer, $5^{\prime}$-GAGTCAACGGATTTGGTCGT- $3^{\prime}$ and antisense primer, $5^{\prime}$-GACAAGCTTCCCGTTGTCAG-3' were used to amplify GAPDH (185 bp). The primers and process for MSP and RT-PCR were as those stated above.

\section{Statistical analyses}

Statistical analyses were performed using SPSS Software version 10.0. Significance was analyzed using the $\chi^{2}$-, $t$-test, and one-way ANOVA. $P<0.05$ was considered statistically significant.

\section{Results}

\section{DKK3 mRNA expression levels in primary tumors}

DKK3 mRNA expression in tumor tissues and their adjacent normal tissues was analyzed using RT-PCR assay (Fig. 1). We were able to detect DKK3 mRNA expression in all the 49 non-cancerous epithelial (NCE) tissue samples, while only 22 of the 49 (44.9\%) PTC tissue samples displayed positive $D K K 3$ mRNA expression, indicating that $D K K 3$ transcriptional repression occurred in at least half of the PTC tissue samples. Further analysis indicated that the mRNA expression of the DKK3 gene was negatively correlated with the tumor pathological grade, TNM stage, and lymph node metastasis $(P<0.05$; Table 1$)$, suggesting a role of the inactivation of $D K K 3$ in the progression of PTC.

\section{Methylation of the $D K K 3$ gene in primary tumors}

No DKK3 promoter methylation was observed in the 49 NCE tissue samples, while 19 of the 49 (38.8\%) PTC tissue
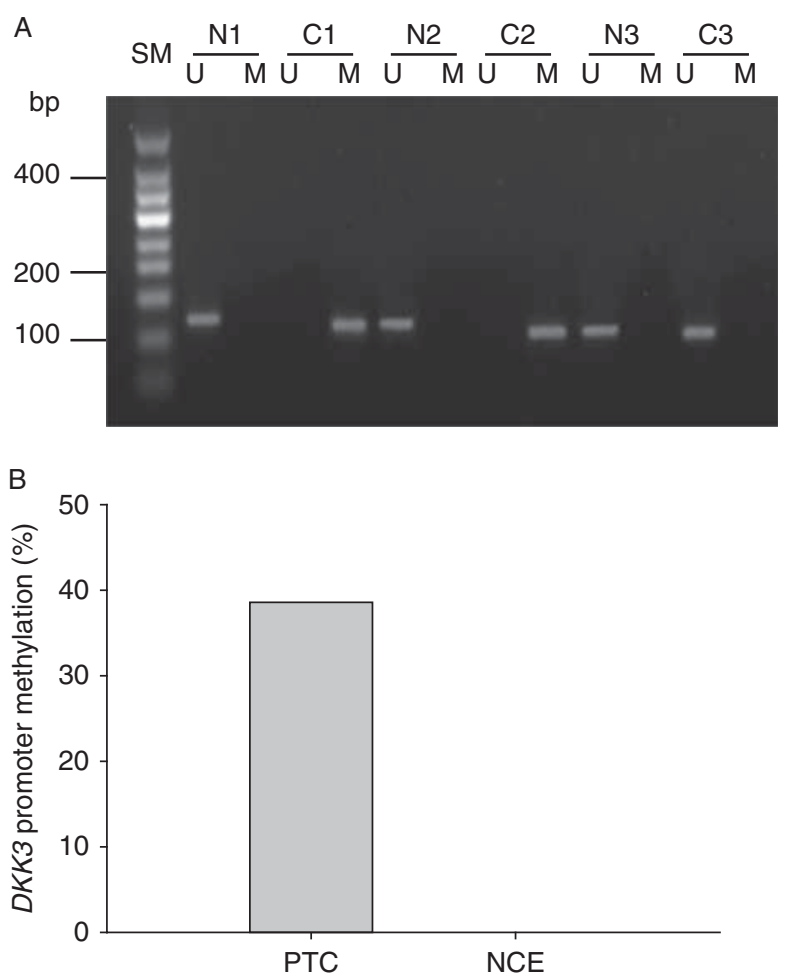

Figure 2

(A) Representative images of DKK3 promoter methylation in PTC tissues and the adjacent non-cancerous epithelial tissues, detected using methylation-specific PCR. (B) Rate of $D K K 3$ promoter hypermethylation in 49 PTC tissue samples and their adjacent non-cancerous epithelial tissue samples. SM, Standard Marker DL-500; C, cancer tissue; N, non-cancerous epithelial tissues; U, unmethylated; M, methylated; PTC, papillary thyroid cancer; NCE, non-cancerous epithelial tissues.

samples exhibited hypermethylation in the $D K K 3$ promoter (Fig. 2). This result indicates that the low expression or abrogation of DKK3 mRNA in PTC might be attributed to the hypermethylation of the $D K K 3$ promoter. The $\chi^{2}$ analysis suggested that the promoter hypermethylation of the $D K K 3$ gene was positively related to the TNM stage, tumor pathological grade, and lymph node metastasis $(P<0.05)$ in PTC (Table 2$)$.

\section{Relationship between the promoter methylation and mRNA expression of $D K K 3$ in PTC}

We further analyzed whether promoter methylation is associated with the downregulation of $D K K 3$ expression in PTC. Among 19 cases with DKK3 promoter hypermethylation, 15 exhibited negative mRNA expression, and the $\chi^{2}$ analysis indicated a negative correlation between the promoter methylation and mRNA expression of DKK3 $(P<0.05$; Table 3). 
Table 2 Relationship between $D K K 3$ promoter hypermethylation and clinicopathological features in PTC.

\begin{tabular}{|c|c|c|c|c|c|c|}
\hline \multirow[b]{2}{*}{ Clinical data } & \multirow[b]{2}{*}{$n$} & \multicolumn{2}{|c|}{ Methylation of $D K K 3$} & \multirow[b]{2}{*}{ Positive rate $(\%)$} & \multirow[b]{2}{*}{$\chi^{2}$} & \multirow[b]{2}{*}{$\boldsymbol{P}$} \\
\hline & & Methylated & Unmethylated & & & \\
\hline \multicolumn{7}{|l|}{ Gender } \\
\hline Male & 18 & 8 & 10 & 44.4 & 0.385 & 0.535 \\
\hline Female & 31 & 11 & 20 & 35.5 & & \\
\hline \multicolumn{7}{|l|}{ Age (years) } \\
\hline$<45$ & 23 & 12 & 11 & 52.2 & 3.278 & 0.07 \\
\hline$\geq 45$ & 26 & 7 & 19 & 27.0 & & \\
\hline \multicolumn{7}{|c|}{ Tumor size $(\mathrm{cm})$} \\
\hline$<2$ & 24 & 12 & 12 & 50.0 & 2.496 & 0.114 \\
\hline$\geq 2$ & 25 & 7 & 18 & 28.0 & & \\
\hline \multicolumn{7}{|l|}{ TNM stage } \\
\hline$|-| \mid$ & 22 & 5 & 17 & 22.8 & 4.331 & $0.037 *$ \\
\hline III-IV & 27 & 14 & 13 & 51.9 & & \\
\hline \multicolumn{7}{|c|}{ Tumor pathological grade } \\
\hline I & 19 & 4 & 15 & 21.1 & 4.106 & $0.043 *$ \\
\hline II & 30 & 15 & 15 & 50.0 & & \\
\hline \multicolumn{7}{|c|}{ Lymph node metastasis } \\
\hline No & 21 & 4 & 17 & 19.0 & 6.025 & 0.014 * \\
\hline Yes & 28 & 15 & 13 & 53.6 & & \\
\hline
\end{tabular}

Effect of a demethylating agent on $D K K 3$ gene expression

To examine the relationship between the expression and methylation of $D K K 3$, we analyzed the effect of the demethylating agent 5 -azaC on the promoter methylation and mRNA expression of the DKK3 gene in TPC-1 cells. As shown in Figs 3 and 4, after treatment of the TPC-1 cells with $5,10,20$, and $50 \mu \mathrm{mol} / 1$ of 5 -azaC for $48 \mathrm{~h}$, the relative expression levels of $D K K 3$ mRNA were $0.208 \pm 0.017,0.365 \pm 0.013,0.489 \pm 0.017$, and 0.582 \pm 0.011 respectively (Fig. 3). Meanwhile, the DKK3 gene was demethylated partially after treatment with 5 -azaC $\left(F_{\mathrm{m}}=315.188, F_{\mathrm{um}}=195.257 ; P<0.05\right.$; Fig. 4$)$. These data indicate that treatment with 5 -azaC significantly enhanced $D K K 3$ mRNA expression, while it reduced $D K K 3$ promoter methylation in the TPC-1 cells, suggesting that $D K K 3$ is indeed epigenetically silenced in TPC-1 cell line.

\section{Discussion}

Epigenetic alterations, such as DNA hypermethylation, play a critical role in tumorigenesis (Schuebel et al. 2007, Ushijima \& Asada 2010). Over the past several years, many TSGs have been found to be epigenetically inactivated in PTC, indicating that epigenetic silencing of TSGs is a major molecular alteration in the tumorigenesis of thyroid carcinoma (Lal et al. 2006, Xing 2007, Yin et al. 2010b, Stephen et al. 2011). It has recently been shown that the methylation of $D K K 3$ gene family contributes to carcinogenesis and serves as a potential biomarker for the diagnosis of several human malignancies (Veeck et al. 2008, 2009, Vander Meide et al. 2011). DKK3 is expressed in many normal human tissues (Hermann et al. 2007, Du et al. 2011), and its expression is downregulated in several human cancers such as lung cancer (Tsuji et al. 2001, Kobayashi et al. 2002, Licchesi et al. 2008, Yue et al. 2008), pancreatic cancer (Hsieh et al. 2004), bladder cancer (Urakami et al. 2006), melanoma (Kuphal et al. 2006), and gastrointestinal tumors (Sato et al. 2007). The role of the $D K K 3$ gene and its epigenetic alterations remain unknown in thyroid cancer.

In this study, we identified $D K K 3$ as another potential TSG whose epigenetic inactivation might contribute to

Table 3 Relationship between the promoter methylation and mRNA expression of $D K K 3$.

\begin{tabular}{lcccc} 
& \multicolumn{2}{c}{ mRNA expression } & \\
\cline { 2 - 3 } $\begin{array}{l}\text { Promoter } \\
\text { methylation }\end{array}$ & + & - & Total \\
\cline { 3 - 4 }+ & 4 & 15 & 19 \\
- & 18 & 12 & 30 \\
Total & 22 & 27 & 49 \\
\hline$\chi^{2}=7.132, P=0.008$. & & &
\end{tabular}

Published by Bioscientifica Ltd 

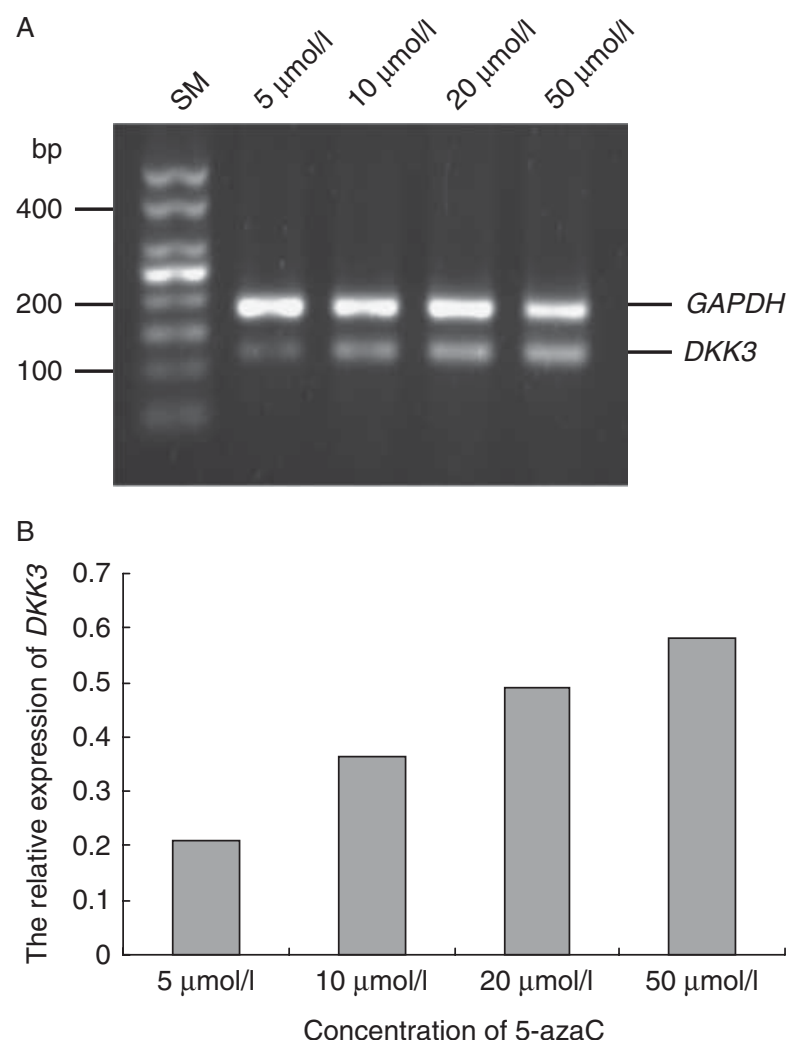

Figure 3

(A) Increase in the expression of DKK3 mRNA detected by RT-PCR in response to the treatment with 5 -azaC in a concentration-dependent manner. (B) Bar graph showing the concentration-dependent effects of 5 -azaC on the expression of $D K K 3$, corresponding to (A). GAPDH was used as a quantitative control. SM, Standard Marker DL-500. Unlike that mentioned in Figs 1 and 2 SM in this figure was obtained from a different company that had no MW marker with $350 \mathrm{bp}$.

the tumorigenesis of PTC. One of the strengths of this study is that both the expression and methylation status of the $D K K 3$ promoter were analyzed in a large number of cases of PTC and their matched NCE tissue samples. The positive rate of $D K K 3$ gene expression in the PTC tissues was significantly lower than that in the NCE tissues $(P<0.01)$. Similar to our study, Kurose et al. (2004) examined 17 pairs of human renal clear-cell carcinoma tissues and their adjacent normal tissues and demonstrated that $D K K 3$ mRNA levels were significantly decreased in carcinoma tissues. In the 49 NCE tissue samples that we examined, no promoter hypermethylation of the $D K K 3$ gene was found, whereas $D K K 3$ promoter methylation was observed in $38.8 \%$ of the cases of PTC. Lodygin et al. (2005) found that abnormal methylation of the DKK3 gene was present in 28 of 41 $(68 \%)$ cases of prostate cancer, but absent in normal controls. We also found that the expression of DKK3
mRNA was lower while the incidence of $D K K 3$ promoter methylation was higher in the cases of PTC that had advanced disease stages or metastasis compared with those that had early disease stages and no metastasis. In addition, we also observed that tumors in which methylation of the $D K K 3$ promoter region was absent had high levels of expression. Using the PTC cell line TPC-1 and a demethylating agent, we were able to functionally link the promoter methylation of $D K K 3$ to decreased $D K K 3$ expression, establishing the promoter methylation of $D K K 3$ as an important mechanism for its inactivation in PTC. Similarly, Roman-Gomez et al. (2004) analyzed CpG island methylation of the $D K K 3$ promoter in six ALL cell lines and found that $D K K 3$ promoter hypermethylation existed in all of them and was associated with decreased DKK3 mRNA expression, which could be restored after exposure to the demethylating agent 5 -azaC. These findings together with ours indicate that the promoter of the $D K K 3$ gene is commonly methylated and silenced in human cancer cells, consistent with its role as a potential TSG. TSG methylation can be associated with BRAF mutation (Hu et al. 2006, Guan et al. 2008), and the later

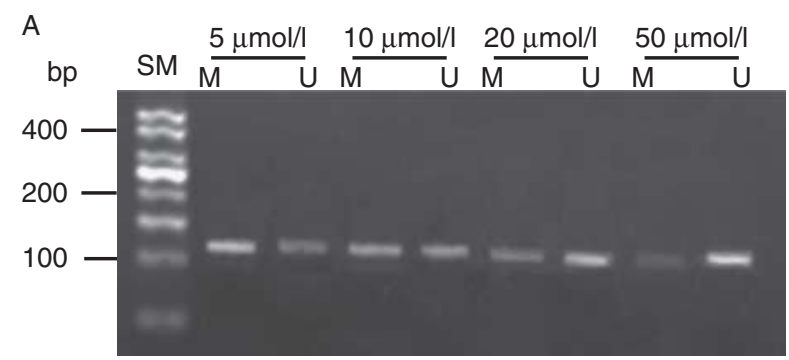

B

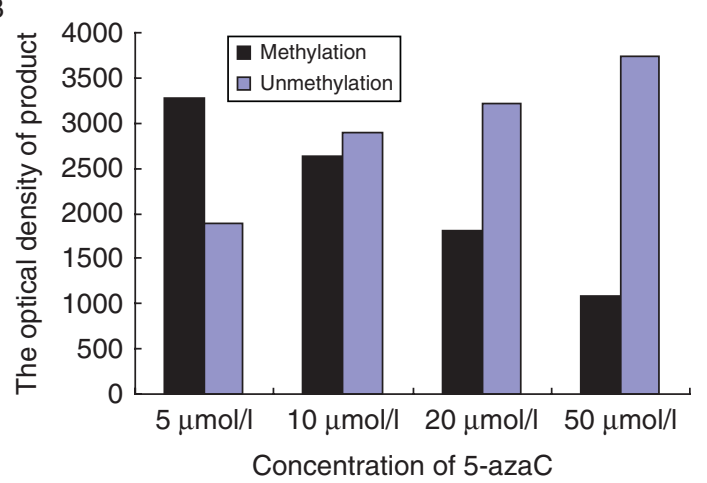

Figure 4

(A) Partial demethylation of the DKK3 gene promoter in TPC-1 cells by treatment with 5-azaC. (B) Bar graph of the results obtained for DKK3 gene demethylation after treatment with 5 -azaC, corresponding to (A). SM, Standard Marker DL-500; U, unmethylated; M, methylated. Unlike that mentioned in Figs 1 and 2, SM in this figure was obtained from a different company that had no MW marker with $350 \mathrm{bp}$. Full colour version of this figure available via http://dx.doi.org/10.1530/ERC-13-0053.

Published by Bioscientifica Ltd. 
is associated with the development of tumor-promoting microenvironments (Nucera et al. 2010). It would be interesting to investigate whether this is the case with the $D K K 3$ gene in a larger study in the future.

Another important finding of this study is that the promoter methylation and decreased expression of the DKK3 gene were associated with aggressive clinicopathological characteristics of PTC, suggesting that the epigenetic inactivation of $D K K 3$ may play an important role in thyroid tumorigenesis and progression and that $D K K 3$ is a major thyroid TSG. As such the hypermethylation of $D K K 3$ may have a prognostic value in the risk stratification of PTC.

In summary, our results suggest that $D K K 3$ is a potential new TSG in PTC. DKK3 may play an important role in the tumorigenesis and aggressiveness of PTC, and the methylation or expression status of $D K K 3$ may be a potentially useful biomarker for evaluating the biological behavior and prognosis of PTC. These results may also bear therapeutic implications for PTC.

\section{Declaration of interest}

The authors declare that there is no conflict of interest that could be perceived as prejudicing the impartiality of the research reported.

\section{Funding}

This work was supported by Henan Medical Science and Technology Project Fund (201201004 D Yin) and Youth Innovation Fund of the First Affiliated Hospital of Zhengzhou University (2011117 D Yin).

\section{References}

Abarzua F, Sakaguchi M, Takaishi M, Nasu Y, Kurose K, Ebara S, Miyazaki M, Namba M, Kumon H \& Huh NH 2005 Adenovirus-mediated overexpression of REIC/Dkk-3 selectively induces apoptosis in human prostate cancer cells through activation of c-Jun-NH2-kinase. Cancer Research 65 9617-9622. (doi:10.1158/0008-5472.CAN-05-0829)

Aleqria-Torres JA, Baccarelli A \& Bollati V 2011 Epigenetics and lifestyle. Epigenetics 3 267-277. (doi:10.2217/epi.11.22)

Ang SJ, Stump RJ, Lovlcu FJ \& McAvoy JW 2004 Spatial and temporal expression of Wnt and Dickkopf genes during murine lens development. Gene Expression Patterns 4 289-295. (doi:10.1016/j.modgep. 2003.11.002)

Davidson G, Mao B, Barco Barrantes I \& Niehrs C 2002 Kremen proteins interact with Dickkopf1 to regulate anteroposterior CNS patterning. Development 129 5587-5596. (doi:10.1242/dev.00154)

Davies L \& Welch HG 2006 Increasing incidence of thyroid cancer in the United States, 1973-2002. JAMA 295 2164-2167. (doi:10.1001/ jama.295.18.2164)

Diep DB, Hoen N, Backman M, Machon O \& Krauss S 2004 Characterisation of the Wnt antagonists and their response to conditionally activated Wnt signaling in the developing mouse forebrain. Brain Research. Developmental Brain Research 153 261-270. (doi:10.1016/j.devbrainres. 2004.09.008)
Du G, Kataoka K, Sakaguchi M, Abarzua F, Than SS, Sonegawa H, Makino T, Shimizu T \& Huh NH 2011 Expression of REIC/Dkk-3 in normal and hyperproliferative epidermis. Experimental Dermatology 20 273-277. (doi:10.1111/j.1600-0625.2010.01244.x)

Fjeld K, Kettunen P, Furmanek T, Kvinnsland IH \& Luukko K 2005 Dynamic expression of Wnt signaling-regulated Dickkopf-1, -2, and -3 mRNAs in the developing mouse tooth. Developmental Dynamics 233 161-166. (doi:10.1002/dvdy.20285)

Fong D, Hermann M, Untergasser G, Pirkebner D, Draxl A, Heitz M, Moser P, Margreiter R, Hengster P \& Amberger A 2009 Dkk-3 expression in the tumor endothelium: a novel prognostic marker of pancreatic adenocarcinomas. Cancer Science 100 1414-1420. (doi:10.1111/j.1349-7006. 2009.01208.x)

Glinka A, Wu W, Delius H, Delius H, Monaghan AP, Blumenstock C \& Niehrs C 1998 Dickkopf-1 is a member of a new family of secreted proteins and functions in head induction. Nature 391 357-362. (doi:10.1038/34848)

Greene FL, Page DL, Fleming ID, Balch CM \& Fritz AG 2002 AJCC Cancer Staging Handbook. 6th ed. New York, NY, USA: Springer Verlag.

Guan H, Ji M, Hou P, Liu Z, Wang C, Shan Z, Teng W \& Xing M 2008 Hypermethylation of the DNA mismatch repair gene hMLH1 and its association with lymph node metastasis and T1799A BRAF mutation in patients with papillary thyroid cancer. Cancer 113 247-255. (doi:10.1002/cncr.23548)

Hermann M, Pirkebner D, Draxl A, Berger P, Untergasser G, Margreiter R \& Hengster P 2007 Dickkopf-3 is expressed in a sub-set of adult human pancreatic $\beta$ cells. Histochemistry and Cell Biology 127 513-521. (doi:10.1007/s00418-007-0278-6)

Hsieh SY, Hsieh PS, Chiu CT \& Chen WY 2004 Dickkopf-3/REIC functions as a suppressor gene of tumor growth. Oncogene $\mathbf{2 3}$ 9183-9189. (doi:10.1038/sj.onc.1208138)

Hu S, Liu D, Tufano RP, Carson KA, Rosenbaum E, Cohen Y, Holt EH, Kiseljak-Vassiliades K, Rhoden KJ, Tolaney S et al. 2006 Association of aberrant methylation of tumor suppressor genes with tumor aggressiveness and BRAF mutation in papillary thyroid cancer. International Journal of Cancer 119 2322-2329. (doi:10.1002/ijc.22110)

Kobayashi K, Ouchida M, Tsuji T, Hanafusa H, Miyazaki M, Namba M, Shimizu N \& Shimizu K 2002 Reduced expression of the REIC/Dkk-3 gene by promoter-hypermethylation in human tumor cells. Gene $\mathbf{2 8 2}$ 151-158. (doi:10.1016/S0378-1119(01)00838-1)

Krupnik VE, Sharp JD, Jiang C, Robison K, Chickering TW, Amaravadi L, Brown DE, Guyot D, Mays G, Leiby K et al. 1999 Functional and structural diversity of the human Dickkopf gene family. Gene 238 301-313. (doi:10.1016/S0378-1119(99)00365-0)

Kuphal S, Lodermeyer S, Bataille F, Schuierer M, Hoang BH \& Bosserhoff AK 2006 Expression of Dickkopf genes is strongly reduced in malignant melanoma. Oncogene 238 301-313. (doi:10.1038/sj.onc.1209508)

Kurose K, Sakaguchi M, Nasu Y, Ebara S, Kaku H, Kariyama R, Arao Y, Miyazaki M, Tsushima T, Namba M et al. 2004 Decreased expression of REIC/Dkk-3 in human renal clear cell carcinoma. Journal of Urology $\mathbf{1 7 1}$ 1314-1318. (doi:10.1097/01.ju.0000101047.64379.d4)

Lal G, Padmanabha L \& Smith BJ 2006 RIZ1 is epigenetically inactivated by promoter. Cancer 107 2752-2759. (doi:10.1002/cncr.22325)

Licchesi JD, Westra WH, Hooker CM, Machida EO, Baylin SB \& Herman JG 2008 Epigenetic alteration of Wnt pathway antagonists in progressive glandular neoplasia of the lung. Carcinogenesis 29 895-904. (doi:10.1093/carcin/bgn017)

Lodygin D, Epanchintsev A, Menssen A, Diebold J \& Hermeking H 2005 Functional epigenomics identifies genes frequently silenced in prostate cancer. Cancer Research 65 4218-4227. (doi:10.1158/0008-5472. CAN-04-4407)

Mao B, Wu W, Davidson G, Marhold J, Li M, Mechler BM, Delius H, Hoppe D, Stannek P, Walter C et al. 2002 Kremen proteins are Dickkopf receptors that regulate Wnt/ $\beta$-catenin signalling. Nature 417 664-667. (doi:10.1038/nature756) 
Monaghan AP, Kioschis P, Wu W, Zuniqa A, Bock D, Poustka A, Delius H \& Niehrs C 1999 Dickkopf genes are co-ordinately expressed in mesodermal lineages. Mechanisms of Development 87 45-56. (doi:10.1016/S0925-4773(99)00138-0)

Nakamura RE \& Hackam AS 2010 Analysis of Dickkopf3 interactions with Wnt signaling receptors. Growth Factors 28 232-242. (doi:10.3109/ $08977191003738832)$

Nie X 2005 Dkk-1,-2, and -3 expression in mouse craniofacial development. Journal of Molecular Histology 36 367-372. (doi:10.1007/s10735-0059008-3)

Nucera C, Porrello A, Antonello ZA, Mekel M, Nehs MA, Giordano TJ, Gerald D, Benjamin LE, Priolo C, Puxeddu E et al. 2010 B-Raf(V600E) and thrombospondin-1 promote thyroid cancer progression. PNAS $\mathbf{1 0 7}$ 10649-51064. (doi:10.1073/pnas.1004934107)

Roman-Gomez J, Jimenez-Velasco A, Agirre X, Castillejo JA, Navarro G, Barrios M, Andreu EJ, Prosper F, Heiniger A \& Torres A 2004 Transcriptional silencing of the Dickkopfs-3 (Dkk-3) gene by CpG hypermethylation in acute lymphoblastic leukaemia. British Journal of Cancer 91 707-713. (doi:10.1038/sj.bjc.6602008)

Sato H, Suzuki H, Toyota M, Nojima M, Maruyama R, Sasaki S, Takagi H, Sogabe Y, Sasaki Y, Idogawa M et al. 2007 Frequent epigenetic inactivation of DICKKOPF family genes in human gastrointestinal tumors. Carcinogenesis 28 2459-2466. (doi:10.1093/ carcin/bgm178)

Schuebel KE, Chen W, Cope L, Glockner SC, Suzuki H, Yi JM, Chan TA, Van Neste L, Van Criekinge W, van den Bosch S et al. 2007 Comparing the DNA hypermethylome with gene mutations in human colorectal cancer. PLoS Genetics 3 1709-1723. (doi:10.1371/journal.pgen. 0030157)

Stephen JK, Chitale D, Narra V, Chen KM, Sawhney R \& Worsham MJ 2011 DNA methylation in thyroid tumorigenesis. Cancers 3 1732-1743. (doi:10.3390/cancers3021732)

Suwa T, Chen M, Hawks CL \& Hornsby PJ 2003 Zonal expression of dickkopf- 3 and components of the Wnt signaling pathways in the human adrenal cortex. Journal of Endocrinology 178 149-158. (doi:10.1677/joe.0.1780149)

Tsuji T, Nozaki I, Miyazaki M, Sakaguchi M, Pu H, Hamazaki Y, Iijima O \& Namba M 2001 Antiproliferative activity of REIC/Dkk-3 and its significant down-regulation in non-small-cell lung carcinomas. Biochemical and Biophysical Research Communications 289 257-263. (doi:10.1006/bbrc.2001.5972)

Urakami S, Shiina H, Enokida H, Kawakami T, Kawamoto K, Hirata H, Tanaka Y, Kikuno N, Nakagawa M, Igawa M et al. 2006 Combination analysis of hypermethylated Wnt-antagonist family genes as a novel epigenetic biomarker panel for bladder cancer detection. Clinical Cancer Research 12 2109-2116. (doi:10.1158/ 1078-0432.CCR-05-2468)

Ushijima T \& Asada K 2010 Aberrant DNA methylation in contrast with mutations. Cancer Science 101 300-305. (doi:10.1111/j.1349-7006. 2009.01434.x)

Vander Meide WF, Snellenberg S, Meijer CJ, Baalbergen A, Helmerhorst TJ, Vander Sluis WB, Snijders PJ \& Steenbergen RD 2011 Promoter methylation analysis of $\mathrm{WNT} / \beta$-catenin signaling pathway regulators to detect adenocarcinoma or its precursor lesion of the cervix. Gynecologic Oncology 123 116-122. (doi:10.1016/j.ygyno.2011.06.015)

Veeck J \& Dahl E 2012 Targeting the Wnt pathway in cancer: the emerging role of Dickkopf-3. Biochimica et Biophysica Acta 1825 18-28. (doi:10.1016/j.bbcan.2011.09.003)

Veeck J, Bektas N, Hartmann A, Kristiansen G, Heindrichs U, Knüchel R \& Dahl E 2008 Wnt signaling in human breast cancer: expression of the putative Wnt inhibitor Dickkopf (Dkk3) is frequently suppressed by promoter hypermethylation in mammary tumors. Breast Cancer Research 10 R82. (doi:10.1186/bcr2151)

Veeck J, Wild PJ, Fuchs T, Schüffler PJ, Hartmann A, Knuchel R \& Dahl E 2009 Prognostic relevance of Wnt-inhibitory factor-1 (WIF1) and Dickkopf-3 (Dkk3) promoter methylation in human breast cancer. BMC Cancer 9 217. (doi:10.1186/1471-2407-9-217)

Xing M 2007 Gene methylation in thyroid tumorigenesis. Endocrinology 148 948-953. (doi:10.1210/en.2006-0927)

Yin DT, Wang L, Sun J, Yin F, Yan Q, Shen RL, Gao JX \& He G 2010 a Homozygous deletion but not mutation of exons 5 and 8 of the fragile histidine triad (FHIT) gene is associated with features of differentiated thyroid carcinoma. Annals of Clinical Laboratory Science $40267-272$.

Yin DT, Wang L, Sun J, Yin F, Yan Q, Shen R, He G \& Gao JX $2010 b$ Association of the promoter methylation and protein expression of fragile histidine triad (FHIT) gene with the progression of differentiated thyroid carcinoma. International Journal of Clinical and Experimental Pathology 3 482-491.

Yin DT, Wang Q, Chen L, Liu MY, Han C, Yan Q, Shen R, He G, Duan W, Li JJ et al. 2011 Germline stem cell gene PIWIL2 mediates DNA repair through relaxation of chromatin. PLOS ONE 6 e27154. (doi:10.1371/ journal.pone.0027154)

Yue W, Sun Q, Dacic S, Landreneau RJ, Siegfried JM, Yu J \& Zhang L 2008 Downregulation of Dkk3 activates $\beta$-catenin/TCF-4 signaling in lung cancer. Carcinogenesis 29 84-92. (doi:10.1093/carcin/bgm267)

Zhang K, Watanabe M, Kashiwakura Y, Li SA, Edamura K, Huang P, Yamaguchi K, Nasu Y, Kobayashi Y, Sakaguchi M et al. 2010 Expression pattern of REIC/Dkk-3 in various cell types and the implications of the soluble form in prostatic acinar development. International Journal of Oncology 37 1495-1501. (doi:10.3892/ijo_00000662)

Received in final form 15 May 2013

Accepted 23 May 2013

Made available online as an Accepted Preprint

23 May 2013 http://erc.endocrinology-journals.org DOI: 10.1530/ERC-13-0053
(C) 2013 Society for Endocrinology Printed in Great Britain
Published by Bioscientifica Ltd. 